\title{
Th/U Relations as an Indicator of the Genesis of Metamorphic Zircons (On the Example of the North of the Urals)
}

\author{
Y. Pystina ${ }^{(\varpi)}$ and A. Pystin \\ Institute of Geology Komi SC UB RAS, Syktyvkar, Russia \\ pystina@geo.komisc.ru
}

\begin{abstract}
Having studied polymetamorphic complexes of the Urals, including its northern part, for many years we have collected material on the basis of which we attempted to make generalizations concerning both the morphology of zircons and their geochemical features, allowing the mineral to be used in the reconstruction of specific metamorphic events and the interpretation of geochronological data (Pystina et al. 2017; Pystina and Pystin 2002). In recent years we also obtained new results on the morphology and geochemistry of zircons from granitoids in the northern part of the Subpolar Urals (Pystina and Pystin 2002). Together, this made it possible to compare different morphological types of magmatic and metamorphic zircons.
\end{abstract}

Keywords: Polymetamorphic complexes - Geochronological - Morphology · Geochemistry of zircons

\section{Introduction}

Precambrian formations, especially Pre-Riphean, which underwent metamorphism, as a rule, experienced it repeatedly, i.e. were polymetamorphic. Accordingly, the zircons of the newly formed, or transformed from the previously existing ones, in the course of these events should have acquired some new properties, expressed in changes in the morphology of the crystals, the internal structure, the geochemical composition. That is what we see in zircons from various polymetamorphic complexes of the Urals, including those located in its northern part: Nyartin, in the Subpolar Urals, and Harbey in the Polar Urals, where up to five morphological types of this mineral are distinguished (Pystina and Pystin 2002).

\section{Results and Discussion}

Detritic zircons (type 1) determine the metamorphic affiliation to one or another source formation. Zircons of the "soccer ball" type or, as is customary in the Urals, after Krasnobayev (1986), call them "granulitic" (type 2), and also "migmatite" (type 4) fix several age levels of occurrences of high-temperature rock transformations. Zircon of irregular shape like "cauliflower" (type 3) is typical for rocks metamorphosed under 
conditions that do not exceed the low to medium stages of the amphibolite facies. In more high-temperature conditions, it is found in the rocks of the basic series. The reason for the emergence of such intricate forms of zircon may be the absence or deficiency of silicate melt. Therefore, when P-T reaches the conditions of metamorphism sufficient for the development of migmatization processes, such zircon can continue to crystallize only in metamorphic mafic composition, for which, as is known, the migmatization temperature is higher. Opaque zircons (type 5) are associated with the manifestation of medium temperature diaphtoresis. The internal structure of all morphotypes of zircons is characterized by the presence of nuclei of irregular or rounded shape, in the "migmatitic" type, oscillatory zonality is usually noted, the "granulitic" type is the most homogeneous. Among the isolated morphotypes of zircons in polymetamorphic complexes, the "granulite" and "migmatite" types prevail. If, by morphological features and internal structure, the zircons of polymetamorphic complexes are surely divided into morphotypes, which can be associated with certain metamorphic events or processes, then the geochemical composition of the scattered elements does not make a clear separation. On the one hand, this is due to the extremely low content of the elements themselves, most often zircon is enriched only in Hf, Y, U, P. C, on the other hand, the nature of the distribution of these elements in the crystal, their quantitative variations do not give grounds to separate some zircon morphotypes from others. Although in some cases it is possible. E.g., in "migmatite" zircons (type 4) from the gneiss of the Harbay Complex, the distribution of Hf decreases from the center of the crystal to the edge, while in other morphotypes of zircons from the same rocks it increases. At the same time, in the gneisses of the Nyartin Complex in all the selected morphotypes, including the "migmatite" type, the content of Hf increases from the center of the crystal to the edge. The same picture, according to our data, is observed in zircons from the rocks of the metamorphic complexes of the Southern Urals: the Alexandrov and Ilmenogorsky (Selyankin block). The content and distribution of the scattered elements according to the data available today with morphological types of zircons are not clearly correlated. In this regard, the $\mathrm{Th} / \mathrm{U}$ ratio deserves interest, which for magmatic zircons are, as a rule, $>0.5$ (Skublov et al. 2009), and for metamorphic, significantly lower $-0.1-0.3$ (Pystin and Pystina 2015a), according to Rubatto < 0.07 (Rubatto 2002), although according to other data it can be $>0.5$, for example, 0.73 in zircons from the eclogite of the Maksyutov Complex (Pystin and Pystina 2015b). But, despite some rebounds in $\mathrm{Th} / \mathrm{U}$ values, the average indices for metamorphic zircons, as well as for magmatic ones, are fairly consistent. In the metamorphic zircons of the gneisses of the Nyartin Complex, obtained from 9 crystals, they vary from 0.02 to 0.39 , but among these values, two are essentially out of the general picture -0.75 and 0.68 . Such values of the $T h / U$ ratio correspond to zircons of magmatic origin. In our case, these are zircons of prismatic habitus, which we have isolated into the "migmatite" type. The isotope age, obtained by the U-Pb SHRIMP-II method, is $503 \pm 8 \mathrm{Ma}$ and $498 \pm 8 \mathrm{Ma}$, respectively (Pystin and Pystina 2008). Their formation was associated with the metamorphism of the amphibolite facies and the associated granitization. Therefore, the conditions, under which this morphotype was formed, were similar to the conditions of granite formation, hence we assume high $\mathrm{Th} / \mathrm{U}$ ratios.

An even clearer picture is obtained for zircons of the "granulitic" type from the Alexandrov Complex in the Southern Urals, where the Th/U ratio varies from 0.23 to 
0.31 , which is quite consistent with the metamorphic zircons. This is confirmed by the isotopic age of all the crystals, which is close and approximately 2.1 Ga (Pystin and Pystina 2015b, Pystina and Pystin 2002).

Our studies show that accessory zircons from rocks of different granitoid complexes in the northern part of the Subpolar Urals, which have different geological positions and isotopic age, differ in the set of morphotypes, their quantitative ratios and geochemical features (Pystina et al. 2017). Recently we studied morphological features of zircons from the granites of Nikolayshor (PR1), Kozhim (PF2-3), Badyayu (RF3V) and Yarota (RF3-V) Massifs. Accessory zircons are very diverse in form, character of zonality, presence of inclusions, color, degree of metamictism and other features. All the main morphological types of zircons according to I.V. Nosyrev (Nosyrev et al. 1989) were observed: zirconium, hyacinth, spear-shaped, torpedo-shaped and citrolite. All of the above morphological types can relate to the generation of zircons of either synpetrogenic or superimposed genetic types.

In the granites of the Nikolashor Massif hyacinth, spear-shaped, torpedo-shaped, and detrital zircons were found. Granitoids of the Kozhimsky, Badyayusky and Yarotsky Massifs are characterized by the presence of three morphotypes of zircons, but if in the granitoids of the Badyayu and Yarota Massifs they are similar (zircon, hyacinth and torpedo-shaped morphotypes), while in the rocks of the Kozhim Massif, they are pattern, torpedo-shaped, torrent, and the beginning of torpedo-shaped morphotypes. Common to the granitoids of all the massifs is one morphotype - torpedo. The spear-shaped zircon is found only in the rocks of the Nikolashor Massif. There are also detrital zircons, which are absent in the granitoids of other massifs. Granites of the Kozhim Massif are distinguished from other granitoids by the presence of zircon of the citrolite morphotype. The presence of this type of zircons is a sign of the metasomatic (or metamorphic) processing of rocks. In contrast to the granites of the Badyayu and Yarota Massifs, they lack hyacinth type zircons.

The $\mathrm{Th} / \mathrm{U}$ ratio in zircons from the granitoids of the northern part of the Subpolar Urals - Nikolashor, Kozhim, Khatalambo-Lapchin and Lapchavozh Massifs, is on average $0.73 ; 0.61 ; 0.51 ; 0.79$, respectively. These values are maintained and observed in all zircons of the studied granitoids. In some cases, in zircons from the granitoids of the Khatalambo-Lapchin Massif, the Th/U values are knocked out of the overall picture, amounting to 0.22 and 0.15 , which is not at all characteristic of magmatic zircons. If we take into account that the age of these zircon crystals obtained by the U-Pb SHRIMP-II method is $703.9 \pm 8 \mathrm{Ma}$ and $795 \pm 41 \mathrm{Ma}$, and the rest of the zircons is 550-580 Ma, we can assume that the formation of ancient zircons The early stages of granite formation and the increased $\mathrm{Th} / \mathrm{U}$ ratio are explained by the subsequent metamorphism of early generation granites.

\section{Conclusions}

Thus, we have to state the validity of the fact that "the only obvious systematic difference between the magmatic and metamorphic zircon is the $\mathrm{Th} / \mathrm{U}$ ratio ..." [Hoskin and Schaltegger 2003, p. 48]. It allows not only to distinguish between 
magmatic zircons from metamorphic, but taking into account the morphological features of individual crystals and isotopic age dating, it is more reliable to restore the history of the formation of specific metamorphic and igneous complexes.

Acknowledgements. This work was supported by the Basic Research Program of the Russian Academy of Sciences No. 18-5-5-19.

\section{References}

Hoskin PWO, Schaltegger U (2003) The composition of zircon and igneous and metamorphic petrogenesis. Rev Miner Geochem 53:27-62

Krasnobayev A (1986) Zircon as an indicator of geological processes. Nauk, Moscow, $152 \mathrm{p}$

Nosyrev IV, Robul VM, Esipchuk KE, Orsa VI (1989) Generation analysis of accessory zircon. Nauka Press, Moscow 203 p

Pystin A, Pystina J (2015a) The early precambrian history of rock metamorphism in the Urals segment of crust. Int Geol Rev 57(11-12):1650-1659

Pystin AM, Pystina YI (2008) Metamorphism and granite formation in the ProterozoicEarlypaleozoic history of the formation of the Polar Ural segment of the earth's crust. Lithosphere (6):25-38

Pystin AM, Pystina YI (2015b) The Archean-Paleoproterozoic history of metamorphism of rocks of the Ural segment of the earth's crust. Works of the Karelian Research Center of the Russian Academy of Sciences, no 7, Geology of Dokembriya, pp 3-18

Pystina YI, Denisova YV, Pystin AM (2017) Typomorphic signs of zircons as a criterion for the dissection and correlation of granitoids (by the example of the northern part of the Subpolar Urals). Bulletin of the Institute of Geology of Komi Scientific Center of the Ural Branch of the Russian Academy of Sciences, no 12, pp 3-15

Pystina Y, Pystin A (2002) Zircon chronicle of the Ural Precambrian. UrD RAS Press, Ekaterinburg, $167 \mathrm{p}$

Rubatto D (2002) Zircon trace element geochemistry: partitioning with garnet and the link between U-Pb ages and metamorphism. Chem Geol 184:123-138

Skublov SG, Lobach-Zhuchenko SB, Guseva NS, et al (2009) Distribution of rare-earth and rare elements in zircons from miaskite lamproites of the Panozersky complex of central Karelia. Geochemistry (9):958-971

Open Access This chapter is licensed under the terms of the Creative Commons Attribution 4.0 International License (http://creativecommons.org/licenses/by/4.0/), which permits use, sharing, adaptation, distribution and reproduction in any medium or format, as long as you give appropriate credit to the original author(s) and the source, provide a link to the Creative Commons license and indicate if changes were made.

The images or other third party material in this chapter are included in the chapter's Creative Commons license, unless indicated otherwise in a credit line to the material. If material is not included in the chapter's Creative Commons license and your intended use is not permitted by statutory regulation or exceeds the permitted use, you will need to obtain permission directly from the copyright holder.

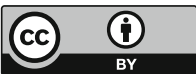

